\title{
The fat and protein fractions of freshwater clam (Corbicula fluminea) extract reduce serum cholesterol and enhance bile acid biosynthesis and sterol excretion in hypercholesterolaemic rats fed a high-cholesterol diet
}

\author{
Takeshi Chijimatsu $^{1,2_{*}}$, Miki Umeki ${ }^{3}$, Yuji Okuda ${ }^{4}$, Koji Yamada ${ }^{5}$, Hiroaki Oda ${ }^{4}$ and Satoshi Mochizuki ${ }^{3}$ \\ ${ }^{1}$ Sasaki Food Company, Limited, 276 Sakai, Bungotakada, Oita 879-0615, Japan \\ ${ }^{2}$ Shizenshokken Company, Limited, Oita 879-0615, Japan \\ ${ }^{3}$ Faculty of Education and Welfare Science, Oita University, Oita 870-1192, Japan \\ ${ }^{4}$ Laboratory of Nutritional Biochemistry, Department of Applied Molecular Biosciences, Nagoya University, \\ Nagoya 464-8601, Japan \\ ${ }^{5}$ Garden for Medical Plants, Graduate School of Biomedical Sciences, Nagasaki University, Nagasaki 852-8521, Japan
}

(Received 10 May 2010 - Revised 13 July 2010 - Accepted 26 August 2010 - First published online 8 October 2010)

\begin{abstract}
We investigated whether the fat and protein fractions of freshwater clam (Corbicula fluminea) extract (FCE) could ameliorate hypercholesterolaemia in rats fed a high-cholesterol diet. We also explored the mechanism and the components that exert the hypocholesterolaemic effect of FCE. The doses of the fat and protein fractions were equivalent to those in $30 \%$ FCE. The fat and protein fractions of FCE, two major components of FCE, significantly reduced the serum and hepatic cholesterol levels. The fat fraction more strongly reduced serum cholesterol levels than the same level of total FCE. The excretion of faecal neutral sterols increased in rats fed the total the FCE and the fat fraction of FCE. On the other hand, faecal bile acid levels were greater in rats fed the total FCE and the fat and protein fractions of FCE than in control animals. The hepatic gene expression of ATP-binding cassette transporter G5 and cholesterol $7 \alpha$-hydroxylase was up-regulated by the administration of the total FCE and both the fat and protein fractions of FCE. These results showed that the fat and protein fractions of FCE had hypocholesterolaemic properties, and that these effects were greater with the fat fraction than with the protein fraction. The present study indicates that FCE exerts its hypocholesterolaemic effects through at least two different mechanisms, including enhanced excretion of neutral sterols and up-regulated biosynthesis of bile acids.
\end{abstract}

Key words: Freshwater clam extract: Fat fraction: Protein fraction: Hypercholesterolaemia

The freshwater clam, a popular edible bivalve in Asia, is thought to have beneficial effects on the liver. We previously reported that a freshwater clam (Corbicula fluminea) extract (FCE) protected against liver injury induced by the administration of D-galactosamine had a hypolipidaemic effect on alcoholic fatty liver and enhanced ethanol metabolism ${ }^{(1)}$. Furthermore, Peng et al. ${ }^{(2)}$ reported that FCE ameliorated liver injury caused by haemorrhage, and its mechanism involved the suppression of plasma TNF- $\alpha$ and an increase in plasma IL-10 levels in rats.

Freshwater clams are effective against hypercholesterolaemia induced by a high-cholesterol diet ${ }^{(3-5)}$ and by exposure to xenobiotics through activation of cholesterogenesis $^{(6)}$. Based on our studies, we speculated that the hypocholesterolaemic effects of FCE might be due to increased faecal neutral sterol and bile acid excretion and enhanced hepatic cholesterol $7 \alpha$-hydroxylase (CYP7A1; EC 1.14.13.7) gene expression ${ }^{(5,6)}$. The major components of FCE are proteins and fats (Table 1). However, the specific ingredients in FCE that exert their hypocholesterolaemic effects remain unclear.

Shellfish contain several lipophilic plant sterols ${ }^{(3-8)}$, which have been reported to reduce cholesterol absorption from the intestine $e^{(3,8-11)}$. Indeed, Iritani et al. ${ }^{(3)}$ suggested that the plant sterols contained in minced freshwater clam elicited a hypocholesterolaemic effect in rats fed a high-cholesterol diet by inhibiting cholesterol absorption. However, the amount of plant sterols in the FCE used in our previous studies was not enough to explain this hypercholesterolaemic effect ${ }^{(5,6)}$, as compared with another study that investigated the hypocholesterolaemic effects of phytosterols $^{(9)}$. It has also been noted that TAG prepared

Abbreviations: ABC, ATP-binding cassette; FCE, freshwater clam extract. 
Table 1. Composition of phytosterols $(\mathrm{g} / 100 \mathrm{~g})$ in the fat fraction of freshwater clam extract (FCE) and fatty acids $(\mathrm{g} / 100 \mathrm{~g})$ in the fat fraction of FCE, lard, maize oil and fish oil

\begin{tabular}{|c|c|c|c|c|}
\hline & $\begin{array}{l}\text { Fat fraction } \\
\text { of FCE }\end{array}$ & Lard $^{*}$ & Maize oil & Fish oil† \\
\hline \multicolumn{5}{|l|}{ Phytosterol } \\
\hline Brassicasterol & 0.22 & & & \\
\hline Campesterol & 0.32 & & & \\
\hline Stigmasterol & 0.12 & & & \\
\hline$\beta$-Sitosterol & 0.05 & & & \\
\hline \multicolumn{5}{|l|}{ Fatty acid } \\
\hline C14:0 & 1.5 & 1.9 & & $5 \cdot 0$ \\
\hline C14:1 & & 0.3 & & 0.1 \\
\hline C15:0 & 0.3 & & & 0.4 \\
\hline C15:1 & & 0.1 & & \\
\hline C16:0 & $18 \cdot 2$ & $25 \cdot 3$ & $10 \cdot 5$ & $19 \cdot 5$ \\
\hline C16:1 & $6 \cdot 3$ & 3.5 & & $6 \cdot 0$ \\
\hline C16:2 & & & & 0.8 \\
\hline C16: 4 & & & & 0.8 \\
\hline $\mathrm{C} 17: 0$ & 1.3 & 0.5 & & $1 \cdot 1$ \\
\hline C17: 1 & 1.2 & 0.4 & & \\
\hline C18:0 & 3.9 & 11.5 & $2 \cdot 0$ & 4.5 \\
\hline C18: $1 n-9$ & $2 \cdot 4$ & 40.5 & 32.5 & $16 \cdot 0$ \\
\hline C18: $1 n-7$ & & & & $2 \cdot 8$ \\
\hline C18:2n-6 & 0.9 & $9 \cdot 3$ & $47 \cdot 3$ & 20.5 \\
\hline C18: $3 n-3$ & 1.7 & 0.7 & 1.4 & 2.5 \\
\hline C18:4n-3 & & & & 1.9 \\
\hline C20:0 & 0.5 & 0.2 & & \\
\hline $\mathrm{C} 20: 1 n-9$ & 0.5 & 0.6 & & 0.9 \\
\hline C20: 4n-6 & 0.6 & 0.3 & & 0.4 \\
\hline $\mathrm{C} 20: 5 n-3$ & & & & $9 \cdot 0$ \\
\hline $\mathrm{C} 22: 5 n-3$ & & & & 1.0 \\
\hline C22: $6 n-3$ & 0.7 & & & $6 \cdot 0$ \\
\hline C24: $1 n-9$ & 0.4 & & & \\
\hline
\end{tabular}

* The data concerning lard and maize oil were quoted from the Standard Tables of Food Composition in Japan, 4th ed. ${ }^{(33)}$.

†The data concerning fish oil was published in de Schrijver et al. ${ }^{(13)}$

from freshwater clams have hypocholesterolaemic actions $^{(4)}$. It seems possible that the hypocholesterolaemic actions of TAG from freshwater clams are elicited by PUFA $^{(4)}$. We have recently found that FCE exerted hypocholesterolaemic effects by increasing the faecal excretion of bile acids and by inducing $C Y P 7 A 1$ gene expression in hypercholesterolaemic rats fed a high-cholesterol diet ${ }^{(5)}$ or a xenobiotic-containing $\operatorname{diet}^{(6)}$. However, phytosterols might not be involved in the increase in faecal bile acid excretion or in the enhancement of CYP7A1 gene expression $^{(10,11)}$. Moreover, contradictory effects of fatty acids on cholesterol catabolism and bile acid excretion have been reported. For example, Morise et al. ${ }^{(12)}$ reported that a linseed diet, rich in PUFA, increased CYP7A1 activity and its gene expression in hamsters, as compared with a butter-based diet, rich in SFA. Meanwhile, de Schrijver et $a l^{(13)}$ reported that a fish oil diet, rich in $n-3$ PUFA, enhanced the faecal excretion of neutral sterols in rats; however, that diet did not affect faecal bile acid excretion, as compared with a beef tallow diet. On the other hand, Høstmark et al. ${ }^{(14)}$ investigated the effect of various oils on the faecal excretion of neutral sterols and bile acid in rats and found that the these were not affected by dietary PUFA $^{(14)}$. Therefore, it remains unclear whether the lipid components are responsible for the hypocholesterolaemic effect of FCE.
FCE contains a relatively high protein content (Table 1). The quality and quantity of proteins in experimental diets are very important factors in terms of cholesterol metabolism in animals. Proteins prepared from some plant materials have been shown to decrease cholesterol levels in experimental animals and in human subjects ${ }^{(15-19)}$. In particular, the hypocholesterolaemic effect of soyabean protein has been extensively studied ${ }^{(15,16,18,19)}$. However, the origin of the proteins - animal or plant - is not important ${ }^{(20)}$. Higaki et al. ${ }^{(19)}$ reported that soyabean-resistant proteins were rich in hydrophobic amino acids and bound to bile acids through hydrophobic interactions. Thus, we speculated that proteins in FCE may exert a hypocholesterolaemic effect in a similar manner to soyabean protein.

Therefore, the aim of the present study was to investigate whether the fat or protein fraction of FCE is responsible for the hypocholesterolaemic effects of FCE. In the present study, we used a widely used diet ${ }^{(21-24)}$ containing high cholesterol levels to induce hyper-VLDL-cholesterolaemia in rats. We found that the fat and protein fractions of FCE successfully lowered the serum cholesterol level, through similar and differing mechanisms. Therefore, FCE exerts its hypocholesterolaemic effects through at least two different pathways.

\section{Materials and methods}

\section{Materials}

The FCE was prepared as described previously ${ }^{(5,6)}$. In brief, freshwater clams (C.fluminea) were steamed until the shells opened, and the edible portions were removed. The edible portion was minced, extracted with boiling water and then filtered through an 80-mesh filter. The filtrate was spray dried for use as the FCE. The yield of FCE from raw material was approximately $1.5 \%(\mathrm{w} / \mathrm{w})$. The FCE contains soluble (65\%) and insoluble (35\%) materials. The approximate composition of FCE (per $100 \mathrm{~g}$ ) is $59.8 \mathrm{~g}$ protein, $11.6 \mathrm{~g}$ carbohydrate, $4.8 \mathrm{~g}$ moisture, $18.2 \mathrm{~g}$ crude fat and $5.6 \mathrm{~g}$ ash.

The FCE was extracted in five volumes of a chloroformmethanol mixture $(2: 1, \mathrm{v} / \mathrm{v})$ overnight. The residues were extracted with the same solvent once. The chloroformmethanol extract was evaporated in a rotary evaporator below $40^{\circ} \mathrm{C}$. The evaporated chloroform-methanol extract was then used as the fat fraction. The fat fraction was obtained from FCE at an 18\% yield (w/w). The concentrations of phytosterols and fatty acids, including PUFA, in the fat fraction are given in Table 1. Palmitic acid (C16:0) was the major fatty acid in the fat fraction of FCE, whereas the concentrations of linoleic acid (C18:2n-6), a major fatty acid in maize oil and fish oil, were relatively low in the fat fraction of FCE. A small amount of DHA (C22:6n-3) was also detected in the fat fraction of FCE. GC/MS analysis of phytosterols and fatty 
acids revealed that these lipid compounds comprised approximately $40 \%$ of the fat fraction of FCE. On the other hand, the TLC analysis of the fat fraction revealed the presence of monoacylglycerols, diacylglycerols and TAG, sterols, carotenoids, sphingolipids and other unidentified components (data not shown). Therefore, the fatty acid concentration of the fat fraction of FCE was lower than that of other lipids (Table 1).

The residue was air dried at room temperature and then suspended with four volumes of $8 \mathrm{~mm}$-sodium acetate buffer ( $\mathrm{pH} 4 \cdot 8$ ). Then, $\beta$-amylase (EC 3.2.1.2, 723 nkat/mg, type II-B, from barley; Sigma-Aldrich, Inc., St Louis, MO, USA) was added at an enzyme:substrate ratio of 1:1000 (w/w) to decompose polysaccharides, mainly glycogen. The incubation continued at room temperature for $2 \mathrm{~h}$, and the samples were boiled for $15 \mathrm{~min}$ to deactivate $\beta$-amylase. The enzymatic decomposition product was added to three volumes of acetone at $-20^{\circ} \mathrm{C}$ overnight to precipitate proteins. The precipitates were air dried at room temperature and then used as the protein fraction. The yield of protein fraction of FCE was $71 \%(\mathrm{w} / \mathrm{w})$.

\section{Animals}

Male Wistar rats (Japan SLC, Inc., Hamamatsu, Japan), aged 4 weeks with a body weight of about $100 \mathrm{~g}$, were housed individually in stainless steel cages. The rats were kept in an environmentally controlled room maintained at $23^{\circ} \mathrm{C}$ with a $12 \mathrm{~h}$ light-dark cycle (lights on 20.0008.00 hours). The rats had free access to food and drinking-water throughout the study. The experimental procedures used in the present study met the guidelines of the Animal Care and Use Committee of Oita University.

\section{Diet}

During the adaptation period, the rats were initially fed a commercial stock diet (5L37; Japan SLC, Inc.) for $3 \mathrm{~d}$ and then fed a $20 \%$ casein diet for $4 \mathrm{~d}$. The compositions of the test diets are given in Table 2. The animals were fed a test diet for $14 \mathrm{~d}$. In our previous study, we compared the diets containing 3, 15 or $30 \%$ FCE and found that $30 \%$ FCE had the most effective cholesterol-lowering effects in cholesterol-loaded rats ${ }^{(5)}$. Moreover, the period of $14 \mathrm{~d}$ was long enough to observe an effect of FCE because the hypocholesterolaemic effect of FCE reached a plateau at 30\% FCE within $14 \mathrm{~d}$. Therefore, we used a $30 \%$ FCE diet for $14 \mathrm{~d}$ in the present experiment. The doses of the fat and protein fractions used in the present experiment were equivalent to those in 30\% FCE. A high-cholesterol diet containing $5 \mathrm{~g}$ cholesterol and $2.5 \mathrm{~g}$ sodium cholate per $\mathrm{kg}$ diet was used in the present study to induce hyper-VLDL-cholesterolaemia. Supplementation with cholesterol and cholate completely suppressed the hepatic gene expression of 3-hydroxy-3-methylglutarylCoA reductase, the rate-limiting enzyme in cholesterol biosynthesis, but had little or no effect on the hepatic gene expression of $C Y P 7 A 1^{(25)}$. The FCE or its extracts were added to the high-cholesterol diet at the expense of casein, sucrose or lard. The level of protein in the diets was adjusted at the expense of sucrose on an isonitrogenous basis. All the diets contained $11 \%$ fat supplied by $1 \%$ maize oil plus $10 \%$ lard (cholesterol-free diet, control diet and protein fraction-containing diet) or $1 \%$ maize oil plus $4.75 \%$ lard plus $5.25 \%$ fat from FCE (FCE diet) or $1 \%$ maize oil plus $4.75 \%$ lard plus $5.25 \%$ of the fat fraction of FCE (FCE fat fraction diet). Mineral mix and vitamin mix were added at concentrations of 35 and $10 \mathrm{~g} / \mathrm{kg}$ diet, respectively.

\section{Sample collection}

Faeces were collected over the last $3 \mathrm{~d}$ of the experimental period (11-14d) and were used to determine the faecal neutral sterol and bile acid levels. The rats in all groups were killed by decapitation at 10.00 hours after a $4 \mathrm{~h}$ fast on the last day of the experimental period. Blood was collected in tubes containing heparin. Liver and adipose tissue

Table 2. Compositions ( $\mathrm{g} / \mathrm{kg}$ diet) of the experimental diets*

\begin{tabular}{|c|c|c|c|c|c|}
\hline & \multirow[b]{2}{*}{ Cholesterol-free diet } & \multicolumn{4}{|c|}{ High-cholesterol diet } \\
\hline & & Control & FCE & Fat fraction of FCE & Protein fraction of $\mathrm{FCE}$ \\
\hline Casein & $200 \cdot 0$ & $200 \cdot 0$ & - & $200 \cdot 0$ & 38.8 \\
\hline Sucrose & 645.0 & 637.5 & 598.5 & 637.5 & 591.7 \\
\hline Maize oil & $10 \cdot 0$ & $10 \cdot 0$ & $10 \cdot 0$ & $10 \cdot 0$ & $10 \cdot 0$ \\
\hline Lard & $100 \cdot 0$ & $100 \cdot 0$ & 47.5 & 47.5 & $100 \cdot 0$ \\
\hline AIN-93G mineral mixture & $35 \cdot 0$ & $35 \cdot 0$ & $35 \cdot 0$ & $35 \cdot 0$ & $35 \cdot 0$ \\
\hline AIN-93 vitamin mixture $†$ & $10 \cdot 0$ & $10 \cdot 0$ & $10 \cdot 0$ & $10 \cdot 0$ & $10 \cdot 0$ \\
\hline Cholesterol & - & $5 \cdot 0$ & $5 \cdot 0$ & $5 \cdot 0$ & $5 \cdot 0$ \\
\hline Sodium cholate & - & 2.5 & $2 \cdot 5$ & 2.5 & $2 \cdot 5$ \\
\hline FCE & - & - & 291.5 & - & - \\
\hline Fat fraction & - & - & - & 52.5 & - \\
\hline Protein fraction & - & - & - & - & 207.0 \\
\hline
\end{tabular}

FCE, freshwater clam extract, AIN, American Institute of Nutrition.

* The level of protein in all experimental diets was adjusted at the expense of sucrose on an isonitrogenous basis. All diets contained $11 \%$ fat. Additionally amounts of mineral mixture and vitamin mixture to the all diet were equal.

† Supplied by Oriental Yeast (Tokyo, Japan). 
were removed rapidly. The livers were immediately frozen and stored for the analysis of hepatic lipids and expression of genes linked to cholesterol metabolism.

\section{Biochemical analysis}

Serum total cholesterol, TAG, NEFA, adiponectin, direct bilirubin, aspartate aminotransferase (EC 2.6.1.1), alanine aminotransferase (EC 2.6.1.2) and alkaline phosphatase (EC 3.1.3.1) were determined using commercial kits. Assay kits for analysing total cholesterol and TAG were purchased from KAINOS Laboratories (Tokyo, Japan). NEFA reagent B was obtained from Sysmex Corporation (Hyogo, Japan). Mouse or rat adiponectin ELISA kits were purchased from Otsuka Pharmaceuticals (Tokyo, Japan). IatroLQ D-BIL(A) was obtained from Mitsubishi Chemical Medience Corporation (Tokyo, Japan). Determiner AST II, Determiner ALT II and Determiner ALP were purchased from Kyowa-Medics, Inc. (Tokyo, Japan). Agarose gel electrophoresis of serum was performed to separate lipoproteins, and lipoprotein cholesterol was stained enzymatically. About $2.5 \mathrm{~g}$ liver were homogenised, and lipids were extracted with a chloroform-methanol mixture $(2: 1$, $\mathrm{v} / \mathrm{v})$, as described by Folch et al. ${ }^{(26)}$. Hepatic total lipids were determined gravimetrically. The concentrations of hepatic cholesterol and TAG in the lipid extracts were determined using the methods described earlier. The concentration of hepatic phospholipids in the lipid extracts was measured using a commercial kit (Phospholipids C-Test: Wako Pure Chemical Industries, Osaka, Japan).

The faecal total neutral sterols and bile acids were extracted using the method described by Delaney et al. ${ }^{(27)}$. The faecal neutral sterols were analysed as trimethylsilyl ester using GC/MS (GC 6890 equipped with 5973MSD and a $30 \mathrm{~m} \times 0.25 \mathrm{~mm} \mathrm{HP}-5 \mathrm{~ms}$ capillary column; Agilent Technologies, Santa Clara, CA, USA), with $5 \alpha$-cholestane as an internal standard. The injector and detector temperatures were 300 and $230^{\circ} \mathrm{C}$, respectively. The initial column temperature was $245^{\circ} \mathrm{C}$, which was held for $2 \mathrm{~min}$ and then increased to $300^{\circ} \mathrm{C}$ at a rate of $2^{\circ} \mathrm{C} / \mathrm{min}$.

Faecal total bile acids were determined enzymatically using the method of Sheltawy \& Losowsky ${ }^{(28)}$ with lithocholic acid as a standard. Although faecal total bile acids were extracted with chloroform-methanol (described earlier), we also evaluated bile acid binding to hydrophobic substances, such as peptides, from FCE in faeces. To achieve this, the faeces were extracted twice in $5 \mathrm{~mm}$ sodium phosphate buffer $(\mathrm{pH} 7 \cdot 4)$, and the precipitate was extracted twice with $75 \%$ ethanol. The bile acids extracted in $75 \%$ ethanol were determined using the methods described earlier. These bile acids are referred to as bile acids binding to faecal hydrophobic substances.

Total RNA was isolated using the method described by Chomczynski \& Sacchi ${ }^{(29)}$, and $20 \mu$ g total RNA were subjected to Northern blot hybridisation. The complementary DNA clones of rat CYP7A1, rat ATP-binding cassette transporter (ABC) G5 and mouse(apo) E were labelled with the Megaprine DNA labelling system (Amersham, Tokyo, Japan) and used for hybridisation. Specific hybridisation was quantified with an image analyser (BAS 2500, Fujifilm, Tokyo, Japan). Because the apo-E mRNA level was not affected by any treatment used in the present study (data not shown), we used it as a normalisation standard $^{(30,31)}$.

\section{Chemical analysis in the fat fraction}

Phytosterols in the fat fraction were analysed using the same method as for faecal neutral sterols. The fat fraction was dissolved in a chloroform-methanol mixture $(2: 1, \mathrm{v} / \mathrm{v})$, and the fatty acids were then methylated in $5 \% \mathrm{HCl} / \mathrm{methanol}$ solution. Fatty acid methyl esters were analysed by GC/MS (GC 6890, 5973MSD; Agilent) equipped with a $30 \mathrm{~m} \times 0.25$ mm BPX70 capillary column (SGE, Ringwood, VIC, Australia). Tricosanoic acid was used as an internal standard. The injector and detector temperatures were 240 and $230^{\circ} \mathrm{C}$, respectively. The initial column temperature was $50^{\circ} \mathrm{C}$, which was held for $2 \mathrm{~min}$ and then increased to $250^{\circ} \mathrm{C}$ at a rate of $4{ }^{\circ} \mathrm{C} / \mathrm{min}$ and held for $15 \mathrm{~min}$ at $250^{\circ} \mathrm{C}$.

\section{Statistics}

All the data are expressed as means with their standard errors. The significance of differences among values was analysed by one-way ANOVA followed by Duncan's multiple-range test ${ }^{(32)}$. The analyses were performed using SPSS version 10.0 (SPSS Japan, Tokyo, Japan). The differences were considered significant at $P<0 \cdot 05$.

\section{Results}

Total FCE and the fat and protein fractions of FCE did not affect body weight, although food intake was slightly higher in the rats fed total FCE and the protein fraction of FCE than in those fed the control diet (Table 3). While a high-cholesterol diet increased the relative liver weight compared with a cholesterol-free diet, total FCE and the protein fraction suppressed this increment. Supplementation of the basal diet with cholesterol decreased the relative weight of epididymal and retroperitoneal adipose tissues. Total FCE and its fat and protein fractions did not affect the weight of adipose tissue. The serum total cholesterol level was significantly higher in the rats fed a high-cholesterol diet than in those fed a cholesterol-free diet (Table 3). The increase in serum cholesterol levels was suppressed by FCE and its fat and protein fractions. In particular, total FCE and its fat fraction dramatically decreased the serum cholesterol level to the level in the rats fed a cholesterol-free diet. Agarose gel electrophoresis revealed that VLDL-cholesterol was greatly reduced by adding total FCE or its fat fraction to a high-cholesterol diet (data not shown). The serum TAG level in the rats 
Table 3. Body weight, food intake, relative organ weight, serum parameters and hepatic lipids in rats fed a cholesterol-free, high-cholesterol, or high-cholesterol diet supplemented with freshwater clam extract (FCE), fat or protein fractions of FCE for $14 \mathrm{~d}$

(Mean values with their standard errors for six rats per group)

\begin{tabular}{|c|c|c|c|c|c|c|c|c|c|c|}
\hline & & & \multicolumn{8}{|c|}{ High-cholesterol diet } \\
\hline & \multicolumn{2}{|c|}{ Cholesterol-free diet } & \multicolumn{2}{|c|}{ Control } & \multicolumn{2}{|c|}{ FCE } & \multicolumn{2}{|c|}{ Fat fraction of FCE } & \multicolumn{2}{|c|}{ Protein fraction of FCE } \\
\hline & Mean & SEM & Mean & SEM & Mean & SEM & Mean & SEM & Mean & SEM \\
\hline \multicolumn{11}{|l|}{ Body wt (g) } \\
\hline Initial & 108 & 2 & 108 & 2 & 108 & 2 & 108 & 2 & 108 & 2 \\
\hline Final & 176 & 4 & 178 & 5 & 184 & 4 & 176 & 3 & 183 & 3 \\
\hline Food intake ( $\mathrm{g}$ for $14 \mathrm{~d}$ ) & $185^{\mathrm{a}}$ & 3 & $187^{\mathrm{a}}$ & 5 & $207^{\mathrm{b}}$ & 4 & $185^{\mathrm{a}}$ & 2 & $201^{\mathrm{b}}$ & 5 \\
\hline \multicolumn{11}{|c|}{ Relative organ wt ( $\mathrm{g} / 100 \mathrm{~g}$ body wt) } \\
\hline \multicolumn{11}{|l|}{ Adipose tissue } \\
\hline Perirenal & 0.13 & 0.01 & 0.14 & 0.01 & 0.12 & 0.01 & 0.14 & 0.01 & 0.11 & $\begin{array}{l}0.08 \\
0.01\end{array}$ \\
\hline Retroperitoneal & $1.29^{b}$ & 0.07 & $1.01^{\mathrm{a}}$ & 0.10 & $1 \cdot 12^{\mathrm{a}, \mathrm{b}}$ & 0.08 & $0.86^{\mathrm{a}}$ & 0.10 & $0.99^{\mathrm{a}}$ & 0.10 \\
\hline \multicolumn{11}{|l|}{ Serum } \\
\hline Total cholesterol (mmol/l) & $2 \cdot 41^{\mathrm{a}}$ & 0.12 & $11 \cdot 6^{\mathrm{c}}$ & 0.9 & $2 \cdot 78^{\mathrm{a}}$ & 0.11 & $3.74^{\mathrm{a}}$ & 0.18 & $7 \cdot 06^{\mathrm{b}}$ & 0.65 \\
\hline TAG $(\mu \mathrm{mol} / \mathrm{l})$ & $604^{\mathrm{b}}$ & 56 & $202^{\mathrm{a}}$ & 23 & $539^{b}$ & 123 & $557^{\mathrm{b}}$ & 148 & $154^{\mathrm{a}}$ & 22 \\
\hline $\mathrm{NEFA}(\mathrm{mEq} / \mathrm{l})$ & $0.992^{\mathrm{a}}$ & 0.033 & $1.41^{\mathrm{c}}$ & 0.05 & $0.985^{a, b}$ & 0.054 & $1 \cdot 17^{\mathrm{b}}$ & 0.05 & $1 \cdot 17^{\mathrm{b}}$ & 0.07 \\
\hline Adiponectin (mg/l) & $2.99^{\mathrm{b}}$ & $0 \cdot 12$ & $2.59^{\mathrm{a}}$ & 0.08 & $3 \cdot 74^{\mathrm{c}}$ & 0.07 & $2 \cdot 52^{\mathrm{a}}$ & 0.12 & $2 \cdot 12^{\mathrm{a}}$ & 0.11 \\
\hline Direct bilirubin $(\mu \mathrm{mol} / \mathrm{l})$ & $0.17^{\mathrm{a}}$ & 0.00 & $0.29^{\mathrm{b}}$ & 0.04 & 0.17 & 0.00 & $0.20^{\mathrm{a}}$ & 0.03 & 0.17 & 0.00 \\
\hline AST $(\mu \mathrm{kat} / /)$ & 3.11 & 0.22 & 3.32 & 0.20 & 3.86 & 0.35 & 3.67 & 0.22 & 3.94 & 0.38 \\
\hline ALT ( $\mu k a t / /)$ & $0.93^{\mathrm{a}}$ & 0.08 & $1 \cdot 32^{\mathrm{b}}$ & 0.13 & $1 \cdot 13^{\mathrm{a}, \mathrm{b}}$ & $0 \cdot 11$ & $0.98^{\mathrm{a}}$ & 0.06 & $1 \cdot 22^{a, b}$ & $0 \cdot 10$ \\
\hline ALP $(\mu k a t / I)$ & $24 \cdot 0^{\mathrm{a}}$ & 0.7 & $38.8^{\mathrm{d}}$ & $1 \cdot 3$ & $26 \cdot 2^{a, b}$ & 0.8 & $27 \cdot 8^{\mathrm{b}}$ & $1 \cdot 1$ & $31.5^{\mathrm{C}}$ & $1 \cdot 0$ \\
\hline \multicolumn{11}{|l|}{ Hepatic lipids } \\
\hline Total lipids (mg/g liver) & $81 \cdot 9^{\mathrm{a}}$ & $6 \cdot 8$ & $173^{\mathrm{d}}$ & 5 & $126^{\mathrm{b}}$ & 2 & $114^{\mathrm{b}}$ & 4 & $156^{\mathrm{c}}$ & 4 \\
\hline Cholesterol ( $\mu \mathrm{mol} / \mathrm{g}$ liver $)$ & $10 \cdot 6^{\mathrm{a}}$ & 0.5 & $56 \cdot 6^{\mathrm{c}}$ & $5 \cdot 2$ & $37 \cdot 3^{\mathrm{b}}$ & 1.7 & $39.4^{\mathrm{b}}$ & 1.8 & $48 \cdot 6^{c}$ & 2.9 \\
\hline TAG ( $\mu \mathrm{mol} / \mathrm{g}$ liver) & $34 \cdot 2^{\mathrm{a}}$ & 4.0 & $61 \cdot 7$ & $6 \cdot 7$ & $36 \cdot 3^{\mathrm{a}}$ & $2 \cdot 0$ & $35 \cdot 1^{\mathrm{a}}$ & $1 \cdot 2$ & $50.0^{\mathrm{b}}$ & $3 \cdot 1$ \\
\hline Phospholipids ( $\mu \mathrm{mol} / \mathrm{g}$ liver) & $30 \cdot 4^{\mathrm{a}}$ & 0.4 & $32 \cdot 6^{a, b}$ & $1 \cdot 3$ & $32 \cdot 4^{a, b}$ & 0.5 & $33.3^{b}$ & 0.7 & $30 \cdot 4^{\mathrm{a}}$ & 1.0 \\
\hline
\end{tabular}

AST, aspartate aminotransferase; ALT, alanine aminotransferase; ALP, alkaline phosphatase.
a,b,c,d Mean values within a row with unlike superscript letters were significantly different $(P<0.05)$. 
fed a high-cholesterol diet was lower than that in the rats fed a cholesterol-free diet. On the other hand, total FCE and its fat fraction suppressed this decrement (Table 3). Although the rats fed a high-cholesterol diet had significantly higher serum NEFA levels than those fed a cholesterol-free diet, dietary supplementation with total FCE or the fat or protein fractions reduced the concentration of serum NEFA. The rats fed a high-cholesterol diet had a significantly lower serum adiponectin concentration than those fed a cholesterol-free diet. However, the serum adiponectin level in the rats fed total FCE was higher than that in the control rats. The fat and protein fractions of FCE did not affect the serum adiponectin level. We also determined the serum activities of aspartate aminotransferase and alanine aminotransferase, markers for hepatocellular injury. Although serum aspartate aminotransferase activity was similar among all the groups (Table 3), the increase in serum alanine aminotransferase induced by the high-cholesterol diet was reduced by the fat fraction of FCE. Dietary supplementation with cholesterol increased serum direct bilirubin and alkaline phosphatase levels, biomarkers for cholestasis, and these increases were suppressed by total FCE and its fat and protein fractions (Table 3).

Total lipids, cholesterol and TAG levels in the liver were higher in the rats fed a high-cholesterol diet than in those fed a cholesterol-free diet (Table 3). Total FCE and the fat and protein fractions of FCE suppressed the increments in hepatic total lipid and TAG levels. The hepatic cholesterol levels in the rats fed total FCE and the fat fraction of FCE were significantly lower than that in the control rats. On the other hand, the protein fraction did not affect the hepatic cholesterol level. By contrast, hepatic phospholipid levels were not affected by supplementation with cholesterol to the basal diet. Diets containing total FCE or the fat or protein fractions did not affect hepatic phospholipid levels compared with the control diet.

The amount of faeces and faecal sterol levels in the last $3 \mathrm{~d}$ of the experimental protocol is summarised in Table 4. The dry weight of the faeces from the rats fed total FCE and the fat and protein fractions was greater than that of the control rats. The amounts of total neutral sterols (the sum of cholesterol, coprostanol and coprostanone) in the faeces of the rats fed FCE or the fat fraction were higher than those of the control rats (Table 4). The rats fed total FCE or the fat fraction had significantly higher faecal levels of total phytosterols (sum of brassicasterol, campesterol, stigmasterol and $\beta$-sitosterol) than the control rats. However, the protein fraction of FCE did not affect the faecal excretion of neutral or plant sterols in the rats fed a high-cholesterol diet. On the other hand, faecal total bile acid excretion was significantly higher in the control rats fed a high-cholesterol diet than in those fed the cholesterol-free diet. The faecal bile acid levels in the rats fed the FCE and the fat and protein fractions of FCE were much higher than those in the control rats (Table 4). To assess the bile acid binding to FCE-derived hydrophobic substances, the bile acids were sequentially extracted from faeces using phosphate buffer and $75 \%$ ethanol, and the bile acids extracted in $75 \%$ ethanol were measured. The amount of bile acids binding to hydrophobic substances was higher in the rats fed the FCE than in those fed a high-cholesterol diet. There were no significant differences in the amount of bound bile acids in faeces between the rats fed the control high-cholesterol diet and those fed the high-cholesterol diets supplemented with the fat or protein fractions of FCE (Table 4).

Table 4. Faeces $(\mathrm{g} / 3 \mathrm{~d})$ and faecal sterols $(\mu \mathrm{mol} / 3 \mathrm{~d})$ in rats fed a cholesterol-free, high-cholesterol, or high-cholesterol diet supplemented with freshwater clam extract (FCE), fat or protein fractions of FCE for $14 \mathrm{~d}$

(Mean values with their standard errors for six rats per group)

\begin{tabular}{|c|c|c|c|c|c|c|c|c|c|c|}
\hline & & & \multicolumn{8}{|c|}{ High-cholesterol diet } \\
\hline & \multicolumn{2}{|c|}{$\begin{array}{l}\text { Cholesterol-free } \\
\text { diet }\end{array}$} & \multicolumn{2}{|c|}{ Control } & \multicolumn{2}{|c|}{ FCE } & \multicolumn{2}{|c|}{$\begin{array}{l}\text { Fat fraction of } \\
\text { FCE }\end{array}$} & \multicolumn{2}{|c|}{$\begin{array}{c}\text { Protein fraction of } \\
\text { FCE }\end{array}$} \\
\hline & Mean & SEM & Mean & SEM & Mean & SEM & Mean & SEM & Mean & SEM \\
\hline Faecal dry wt & $0.94^{a}$ & 0.07 & $0.94^{a}$ & 0.08 & $3.7^{d}$ & $0 \cdot 1$ & $1 \cdot 6^{\mathrm{b}}$ & 0.0 & $2 \cdot 7^{c}$ & $0 \cdot 1$ \\
\hline Cholesterol & $4.80^{\mathrm{a}}$ & 0.96 & $72 \cdot 9^{b}$ & 11.5 & $381^{d}$ & 24 & $302^{\mathrm{c}}$ & 16 & $113^{\mathrm{b}}$ & 7 \\
\hline Coprostanol & $21.6^{\mathrm{d}}$ & 1.5 & $12 \cdot 3^{C}$ & 1.2 & $1 \cdot 29^{a, b}$ & 0.87 & $4 \cdot 61^{\mathrm{b}}$ & 1.84 & $0.09^{a}$ & 0.04 \\
\hline Coprostanone & $0.84^{\mathrm{a}}$ & 0.15 & $0.73^{a}$ & $0 \cdot 16$ & $2 \cdot 99^{\mathrm{a}}$ & 1.98 & $10 \cdot 5^{\mathrm{b}}$ & 4.0 & $0.71^{a}$ & 0.48 \\
\hline Total neutral sterols* & $27 \cdot 3^{\mathrm{a}}$ & $2 \cdot 0$ & $85 \cdot 9^{b}$ & 11.4 & $386^{d}$ & 26 & $317^{c}$ & 18 & $114^{\mathrm{b}}$ & 7 \\
\hline Brassicasterol & $0^{a}$ & 0 & $0^{a}$ & 0 & $31.0^{\mathrm{C}}$ & $2 \cdot 1$ & $23.7^{\mathrm{b}}$ & 1.1 & $0^{\mathrm{a}}$ & 0 \\
\hline Campesterol & $0.30^{\mathrm{a}}$ & 0.11 & $0.83^{\mathrm{a}}$ & 0.13 & $48 \cdot 9^{c}$ & $3 \cdot 8$ & $38.5^{\mathrm{a}}$ & $2 \cdot 4$ & $1.01^{\mathrm{a}}$ & $0 \cdot 11$ \\
\hline Stigmasterol & $0^{a}$ & 0 & $0^{a}$ & 0 & $24 \cdot 1^{\mathrm{c}}$ & 1.9 & $18 \cdot 9^{b}$ & $1 \cdot 1$ & $0^{\mathrm{a}}$ & 0 \\
\hline$\beta$-Sitosterol & $0.49^{\mathrm{a}}$ & 0.13 & $2 \cdot 69^{\mathrm{a}}$ & 0.61 & $19 \cdot 9^{\mathrm{b}}$ & $1 \cdot 7$ & $17 \cdot 7^{\mathrm{b}}$ & $1 \cdot 2$ & $2.08^{\mathrm{a}}$ & 0.11 \\
\hline Total phytosterols $†$ & $0.78^{a}$ & 0.22 & $3.52^{a}$ & 0.74 & $124^{\mathrm{c}}$ & 9 & $98 \cdot 8^{b}$ & $5 \cdot 8$ & $3.09^{a}$ & 0.21 \\
\hline Total bile acids & $20 \cdot 4^{\mathrm{a}}$ & 3.4 & $154^{b}$ & 12 & $325^{d}$ & 20 & $287^{c}$ & 10 & $282^{c}$ & 7 \\
\hline $\begin{array}{l}\text { Bile acids binding to } \\
\text { hydrophobic substance }\end{array}$ & $11 \cdot 9^{\mathrm{a}}$ & $2 \cdot 0$ & $89 \cdot 3^{b}$ & $7 \cdot 7$ & $134^{\mathrm{C}}$ & 16 & $114^{\mathrm{b}, \mathrm{c}}$ & 8 & $99 \cdot 4^{\mathrm{b}}$ & $10 \cdot 5$ \\
\hline
\end{tabular}

a,b,c,d Mean values within a row with unlike superscript letters were significantly different $(P<0.05)$.

* Total neutral sterols $=$ cholesterol + coprostanol + coprostanone.

$\dagger$ Total phytosterols $=$ brassicasterol + campesterol + stigmasterol $+\beta$-sitosterol.

$\ddagger$ Bile acids were sequentially extracted from faeces with phosphate buffer and $75 \%$ ethanol, and then the bile acids extracted with $75 \%$ ethanol were measured. These bile acids were referred to as bile acids binding to hydrophobic substance. 


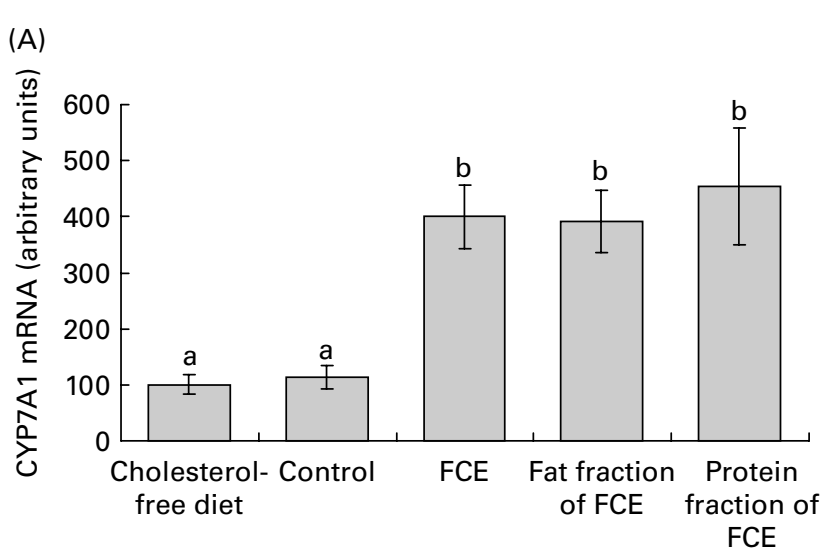

High-cholesterol diet

(B)

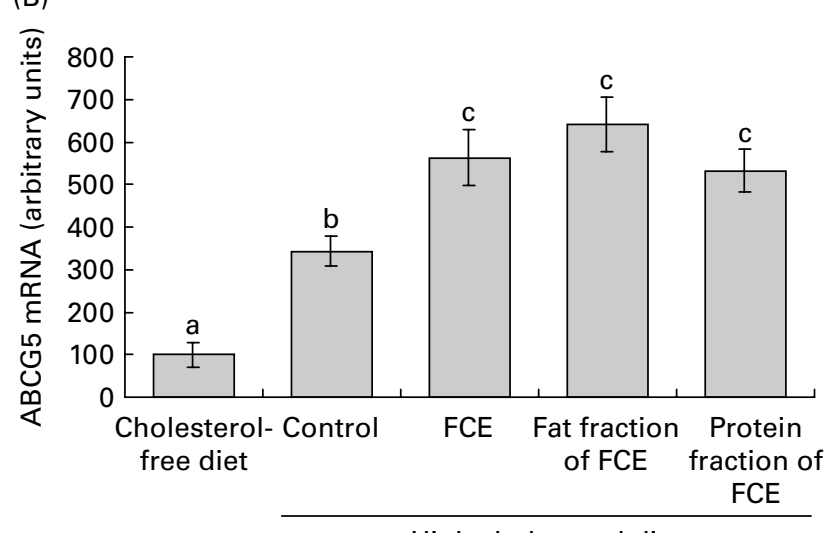

High-cholesterol diet

Fig. 1. Hepatic mRNA levels of CYP7A1 (A) and ABCG5 (B) in the rats fed a cholesterol-free, high-cholesterol or high-cholesterol diet supplemented with freshwater clam extract (FCE) or the fat or protein fractions of FCE for $14 \mathrm{~d}$. Values are means, with their standard errors represented by vertical bars $(n 6)$. $\mathrm{a}, \mathrm{b}, \mathrm{c}$ Mean values with unlike letters were significantly different $(P<0.05)$.

The concentrations of hepatic CYP7A1 and ABCG5 mRNA are shown in Fig. 1. The mRNA level of hepatic CYP7A1, the rate-limiting enzyme in the metabolic pathway from cholesterol to bile acid, was significantly higher in the rats fed total FCE and the fat and protein fraction of FCE than in those fed a cholesterol-free diet and a high-cholesterol control diet (Fig. 1(A)). ABCG5 is mainly expressed in the liver and the intestine, and hepatic ABCG5 plays a critical role in the excretion of cholesterol from the liver to bile. The hepatic mRNA level of ABCG5 was higher in the rats fed a high-cholesterol diet than in those fed a cholesterol-free diet, which was greatly amplified by FCE and its fat and protein fractions (Fig. 1(B)).

\section{Discussion}

In previous studies, we reported that dietary supplementation with FCE ameliorated hypercholesterolaemia induced both by a high-cholesterol diet $^{(5)}$ and by exposure to xenobiotics $^{(6)}$. The hypocholesterolaemic action of FCE was thought to be due to increased excretion of neutral sterols and bile acids into faeces and enhanced hepatic
CYP7A1 gene expression. However, the components of FCE responsible for its hypocholesterolaemic effects have not been elucidated. In the present study, we focused on the major components of FCE - the fat and protein fractions - to examine whether these fractions had cholesterollowering effects in the hypercholesterolaemic rats induced by feeding them a high-cholesterol diet. The present study showed that the fat and protein fractions of FCE significantly decreased serum and hepatic cholesterol levels (Table 3), and that the hypocholesterolaemic effect was greater with the fat fraction than with the protein fraction.

Iritani et al. ${ }^{(3,4)}$ suggested that the ingredients of freshwater clams responsible for this hypocholesterolaemic effect were phytosterols and PUFA. Sugano et al. ${ }^{(9)}$ conducted a study to determine the dose-dependent effects of plant sterols on cholesterol metabolism in rats fed a high-cholesterol diet. They found that the serum cholesterol level in the rats fed a diet containing $0 \cdot 1 \%$ phytosterol and $1 \%$ cholesterol was same as that in the rats fed a diet containing $1 \%$ cholesterol $^{(9)}$. The concentrations of phytosterols in the diets containing total FCE and the fat fraction were less than $0.04 \%$ (Tables 1 and 2). Therefore, the amount of phytosterols in FCE used in the present study is unlikely to be sufficient to exert a hypocholesterolaemic effect. The amount of PUFA in the FCE was similar to that of lard ${ }^{(33)}$ but was lower than that of maize oil ${ }^{(33)}$ and fish oil ${ }^{(13)}$ (Table 1). Furthermore, several papers have shown contradictory results. For example, Jia et al. $^{\left({ }^{(3)}\right)}$ reported that a diet containing $0.25 \%$ cholesterol up-regulated hepatic $A B C G 5$ gene expression, whereas supplementing a high-cholesterol diet with $1 \%$ phytosterols did not up-regulate, as compared with a cholesterol-free diet in hamsters. Unfortunately, few studies have investigated the effects of PUFA on the hepatic expression of the $A B C G 5$ and $G 8$ genes. Moreover, the faecal excretion of bile acids was increased in the rats fed the fat fraction of FCE (Table 4). In earlier studies, phytosterols ${ }^{(10,11)}$ and PUFA-rich marine oil ${ }^{(13,14)}$ did not promote the excretion of bile acid into faeces. Therefore, phytosterols and PUFA are not the major contributors to the FCE-promoted excretion of faecal neutral sterols and bile acids. These data suggest the presence of ingredients other than plant sterols or PUFA responsible for the hypocholesterolaemic effect of FCE.

TLC analysis revealed that the fat fraction of FCE contains many varieties of compounds (data not shown). Maoka et $a l .{ }^{(35)}$ reported the presence of several known and novel carotenoids in freshwater clams. They reported that lutein, a major carotenoid in freshwater clams, reflected the carotenoids present in their dietary algae ${ }^{(35)}$. Although we did not investigate the presence of carotenoids or any other substances in the fat fraction of FCE, the diversity of ingredients in the fat fraction of FCE may explain its hypocholesterolaemic effects.

Ikeda et al. ${ }^{(36)}$ recently reported that the ingestion of soya protein enhanced hepatic ABCG5 and G8 gene 
expression and accelerated biliary cholesterol excretion in rats, although the faecal neutral sterol excretion was not affected. In a similar manner, we found that the protein fraction of FCE up-regulated the hepatic ABCG5 mRNA expression, without affecting the faecal neutral sterol excretion (Table 4, Fig. 1(A)). Higaki et al. ${ }^{(19)}$ speculated that peptides present in soya protein bound bile acids, and these bile acids were then excreted into faeces. The rats fed FCE or the protein fraction of FCE excreted a higher amount of faeces than the rats fed the control diet (Table 4). This indicates that the FCE contained some indigestible peptides. However, the amount of bile acids bound to hydrophobic substances was not affected by the protein fraction of FCE (Table 4). Although hepatic CYP7A1 gene expression was enhanced by FCE (Fig. 1(A)), small heterodimer partner gene expression, a negative regulator of CYP7A1 transcription through farnesoid $X$ receptors ${ }^{(37,38)}$, was not affected by $\mathrm{FCE}^{(5,6)}$. Therefore, these data indicate that hydrophobic substances present in the FCE protein fraction did not explain the increased faecal excretion of bile acids or the reduction in serum cholesterol. On the other hand, the amino acid composition of proteins plays an important role in cholesterol metabolism ${ }^{(20)}$. We have already shown that the level of glycine in FCE was three times higher than that in casein, and that the level of sulphur-containing amino acids in FCE was equal to that in casein ${ }^{(6)}$. Sugiyama et $a l^{(39)}$ and we ${ }^{(20)}$ have demonstrated that glycine and sulphur-containing amino acids reduced the plasma cholesterol level in rats fed a high-cholesterol diet. Although we have not investigated how the proteins present in FCE were responsible for the hypocholesterolaemic effects, we speculate that the amino acid composition and some still unknown bioactive peptides can explain the hypocholesterolaemic effects of FCE.

In the present study, we have clearly shown that the fat and protein fractions of FCE had hypocholesterolaemic effects. In addition, the present results suggest that FCE provides benefits in terms of the metabolic syndrome, liver injury and cholestasis. Serum alanine aminotransferase activity was suppressed by the fat fraction of FCE (Table 3). The increases in serum direct bilirubin and alkaline phosphatase induced by the high-cholesterol diet were also suppressed by dietary supplementation with FCE. The metabolic syndrome is a collection of obesity-related disorders and is usually accompanied by insulin resistance and chronically elevated plasma NEFA levels ${ }^{(40)}$. Here, we showed that the serum levels of NEFA were decreased in the rats fed total FCE or its fat and protein fractions. Furthermore, the serum levels of adiponectin were increased by FCE (Table 3). These results suggest that FCE may have beneficial functions in terms of the metabolic syndrome and life-related diseases.

The present study revealed that the fat and protein fractions of FCE had hypocholesterolaemic effects. Therefore, FCE, a mixture of the protein and fat fractions, had marked cholesterol-lowering effects. Furthermore, these hypocholesterolaemic effects were mediated by changes in the gene expression of $A B C G 5$ and $C Y P 7 A 1$. However, the mechanisms underlying the regulation of these genes are still unclear. It has been recently reported that some microRNA, a new class of small non-coding RNA, regulate cholesterol metabolism ${ }^{(41,42)}$. Therefore, the analysis of transcriptional factors and microRNA microarray analyses will help reveal the regulatory mechanism of these genes in the rats fed the diets containing FCE or its fat and protein fractions. On the other hand, the fat and protein fractions had different effects on the faecal neutral sterol and bile acid excretion. Therefore, the mechanisms underlying the effects of both the fractions are likely to be different. In the present study, we found an extensive array of lipophilic compounds in the fat fraction of FCE (data not shown). Future studies will focus on identifying the lipophilic ingredients responsible for the hypocholesterolaemic effects of FCE. In the present study, we used an exogenous hypercholesterolaemic rat model to investigate the hypocholesterolaemic effect of the fat and protein fractions of FCE. This model is useful to investigate hyper-very low-density lipoproteinaemia. However, in the exogenous hypercholesterolaemic model, hepatic cholesterogenesis is completely suppressed by excess dietary cholesterol. Clinically, the causes of hypercholesterolaemia include exogenous and endogenous cholesterol. Therefore, we believe that it is important to investigate the hypocholesterolaemic effects of nutrition or drugs in exogenous and endogenous hypercholesterolaemic models. Finally, further studies are needed to examine whether the fat and protein fractions of FCE exert hypocholesterolaemic effects in an endogenous hypercholesterolaemic animal model.

\section{Acknowledgements}

This research received no specific grant from other institutions. None of the authors has any conflicts of interest to declare. T. C., H. O. and S. M. designed the research; T. C., M. U., Y. O., K. Y. and S. M. conducted the research; T. C. performed the data analysis, and T. C., H. O. and S. M. wrote the manuscript.

\section{References}

1. Chijimatsu T, Yamada A, Miyaki H, et al. (2008) Effect of fresh water clam (Corbicula fluminea) extract on liver function in rats. Nippon Shokubinkagaku Kougaku Kaishi $\mathbf{5 5}$, 63-68, (in Japanese).

2. Peng TC, Subeq YM, Lee CJ, et al. (2008) Freshwater clam ameliorates acute liver injury induced by hemorrhage in rats. Am J Chin Med 36, 1121-1133.

3. Iritani N, Fukuda E \& Inoguchi K (1979) Effect of feeding the shell fish (Coribula japonica) on lipid metabolism in the rat. Atherosclerosis 34, 41-47.

4. Iritani N, Fukuda E, Inoguchi K, et al. (1980) Reduction of lipogenic enzymes by shellfish triglycerides in rat liver. $J$ Nutr 110, 1664-1670. 
5. Chijimatsu T, Tatsuguchi I, Abe K, et al. (2008) A freshwater clam (Corbicula fluminea) extract improves cholesterol metabolism in rats fed on a high-cholesterol diet. Biosci Biotechnol Biochem 72, 2566-2571.

6. Chijimatsu T, Tatsuguchi I, Oda H, et al. (2009) A freshwater clam (Corbicula fluminea) extract reduces cholesterol level and hepatic lipids in normal and xenobiotics-induced hypercholesterolemic rats. J Agric Food Chem 57, 3108-3112.

7. Kritchevsky D, Tapper SA, DiTullo NW, et al. (1967) The sterols of seafood. J Food Sci 32, 64-66.

8. Vahouny GV, Connor WE, Roy T, et al. (1981) Lymphatic absorption of shellfish sterols and their effects on cholesterol absorption. Am J Clin Nutr 34, 507-513.

9. Sugano M, Kamo F, Ikeda I, et al. (1976) Lipid-lowering activity of phytostanols in rats. Atherosclerosis 24, 301-309.

10. Uchida K, Takase H, Nomura Y, et al. (1984) Changes in biliary and fecal bile acids in mice after treatments with diosgenin and $\beta$-sitosterol. J Lipid Res 25, 236-245.

11. Plsöch T, Kruit JK, Bloks VW, et al. (2006) Reduction of cholesterol absorption by dietary plant sterols and stanols in mice is independent of the ABCG5/8 transporter. $J$ Nutr 136, 2135-2140.

12. Morise A, Sérougne C, Gripois D, et al. (2004) Effects of dietary alpha linolenic acid on cholesterol metabolism in male and female hamsters of the LPN strain. J Nutr Biochem 15, 51-61.

13. de Schrijver R, Vermeulen D \& Daems V (1992) Doseresponse relationships between dietary $(n-3)$ fatty acids and plasma and tissue lipids, steroid excretion and urinary malondialdehyde in rats. J Nutr 122, 1979-1987.

14. Høstmark AT, Lystad E, Haug A, et al. (1989) Plasma lipids, lipoproteins, and fecal excretion of neutral sterols and bile acids in rats fed various high fat diets or a low fat/high sucrose diet. J Nutr 119, 356-363.

15. Roy DM \& Schneeman BO (1981) Effect of soy protein, casein and trypsin inhibitor on cholesterol, bile acids and pancreatic enzymes in mice. J Nutr 111, 878-885.

16. Tanaka K, Aso B \& Sugano M (1984) Biliary steroid excretion in rats fed soybean protein and casein or their amino acid mixtures. J Nutr 114, 26-32.

17. Kayashita J, Shimaoka I, Nakajoh M, et al. (1997) Consumption of buckwheat protein lowers plasma cholesterol and raises fecal neutral sterols in cholesterol-fed rats because of its low digestibility. J Nutr 127, 1395-1400.

18. Wong WW, Smith EO, Stuff JE, et al. (1998) Cholesterol-lowering effect of soy protein in normocholesterolemic and hypercholesterolemic men. Am J Clin Nutr 69, 1385S-1389S.

19. Higaki N, Sato K, Suda H, et al. (2006) Evidence for the existence of a soybean resistant protein that captures bile acid and stimulates its fecal excretion. Biosci Biotechnol Biochem 70, 2844-2852.

20. Oda H (2006) Functions of sulphur-containing amino acids in lipid metabolism. J Nutr 136, 1666S-1669S.

21. Dolphin PJ (1981) Serum and hepatic nascent lipoproteins in normal and hypercholesterolemic rats. J Lipid Res 22, 971-989.

22. Fungwe TV, Cagen L, Wilcox HG, et al. (1992) Regulation of hepatic secretion of very low density lipoprotein by dietary cholesterol. J Lipid Res 33, 179-191.

23. Fungwe TV, Cagen LM, Cook GA, et al. (1993) Dietary cholesterol stimulates hepatic biosynthesis of triglyceride and reduces oxidation of fatty acids in the rat. $J$ Lipid Res 34, 933-941.

24. Wang YM, Zhang B, Xue Y, et al. (2010) The mechanism of dietary cholesterol effects on lipids metabolism in rats. Lipids Health Dis 9, 4-9.
25. Shefer S, Nguyen LB, Salen G, et al. (1992) Differing effects of cholesterol and taurocholate on steady state hepatic HMG-CoA reductase and cholesterol $7 \alpha$-hydroxylase activities and mRNA levels in the rat. J Lipid Res 33, 1193-1200.

26. Folch J, Lees M \& Sloane Stanley GH (1957) A simple method for the isolation and purification of total lipides from animal tissues. J Biol Chem 226, 497-509.

27. Delaney B, Nicolosi RJ, Wilson TA, et al. (2003) $\beta$-Glucan fractions from barley and oats are similarly antiatherogenic in hypercholesterolemic Syrian golden hamsters. J Nutr 133, $468-475$.

28. Sheltawy MJ \& Losowsky MS (1975) Determination of fecal bile acids by an enzymatic method. Clin Chim Acta 64 , $127-132$.

29. Chomczynski P \& Sacchi N (1987) Single-step method of RNA isolation by acid guanidinum thiocyanate-phenolchloroform extraction. Anal Biochem 162, 156-159.

30. Oda H, Nozawa K, Hitomi Y, et al. (1995) Laminin-rich extracellular matrix maintains high level of hepatocyte nuclear factor 4 in rat hepatocyte culture. Biochem Biophys Res Commun 212, 800-805.

31. Yoshida Y, Kimura N, Oda H, et al. (1996) Insulin suppresses the induction of CYP2B1 and CYP2B2 gene expression by phenobarbital in adult rat cultured hepatocytes. Biochem Biophys Res Commun 229, 182-188.

32. Duncan DB (1955) Multiple range and multiple $F$ tests. Biometrics 11, 1-45.

33. The Science and Technology Agency of Japan (1982) Standard Tables of Food Composition in Japan, 4th ed. Tokyo: Ministry of Finance Printing Bureau.

34. Jia X, Ebine N, Demonty I, et al. (2007) Hypocholesterolemic effects of plant sterol analogues are independent of ABCG5 and ABCG8 transporter expressions in hamsters. Br J Nutr 98, 550-555.

35. Maoka T, Fujiwara Y, Hashimoto K, et al. (2005) Carotenoids in three species of corbicula clams, Corbicula japonica, Corbicula sandai, and Corbicula sp. (Chinese freshwater Corbicula clam). J Agric Food Chem 53, 8357-8364.

36. Ikeda I, Kudo M, Hamada T, et al. (2009) Dietary soy protein isolate and its undigested high molecular fraction upregulate hepatic ATP-binding cassette transporter G5 and ATPbinding cassette transporter G8 mRNA and increase biliary secretion of cholesterol in rats. J Nutr Sci Vitaminol $\mathbf{5 5}$, $252-256$.

37. Lu TT, Makishima M, Repa JJ, et al. (2000) Molecular basis for feedback regulation of bile acid synthesis by nuclear receptors. Moll Cell 6, 507-515.

38. Goodwin B, Jones SA, Price RR, et al. (2000) A regulatory cascade of the nuclear receptors FXR, SHP-1, and LRH-1 represses bile acid biosynthesis. Moll Cell 6, 517-526.

39. Sugiyama K, Kushima Y \& Muramatsu K (1985) Effects of sulphur-containing amino acids and glycine on plasma cholesterol level in rats fed on a high cholesterol diet. Agric Biol Chem 49, 3455-3461.

40. Lam TKT, Yoshii H, Haber CA, et al. (2002) Free fatty acid-induced hepatic insulin resistance: a potential role for protein kinase C- $\delta$. Am J Physiol Endocrinol Metab 283, E682-E691.

41. Esau C, Davis S, Murray SF, et al. (2006) miR-122 regulation of lipid metabolism revealed by in vivo antisense targeting. Cell Metab 3, 87-98.

42. Takagi S, Nakajima M, Kida K, et al. (2010) MicroRNAs regulate human hepatocyte nuclear factor $4 \mathrm{a}$, modulating the expression of metabolic enzymes and cell cycle. J Biol Chem 285, 4415-4422. 